\title{
Paul Allen Miller, Horace, (Understanding Classics), I. B. Tauris, London-New York 2019, 201 pp., ISBN 978-1-78453-330-4
}

I. B. Tauris issues its Understanding Classics series with an aim to familiarise the general educated readership with outstanding authors and thinkers of antiquity. Individual volumes do not have the character of a biographies or popular companions; instead, they focus on the selected, most salient aspects of authors' works: their subjects, their poetic registers and their broad socio-political milieu. Therefore, a degree of familiarity with the subject matter is expected: these volumes will best serve readers such as graduate students of classics, literature, philosophy or ancient history, deepening their understanding of well-known authors.

Such is also the character of the latest contribution to the series on Horace by Paul Allen Miller, Professor of Classics and Comparative Literature in the Department of Languages, Literatures, and Cultures at the University of South Carolina, Columbia. Miller, a specialist in Roman poetry of the Augustan Age and reception of ancient philosophy, authored a great number of monographs, including Lyric Texts and Lyric Consciousness: The Birth of a Genre from Archaic Greece to Augustan Rome (1994), Latin Erotic Elegy: An Anthology and Critical Reader (2002), Latin Verse Satire: An Anthology and Critical Reader (2005) (Routledge), Subjecting Verses: Latin Love Elegy and the Emergence of the Real (2004) (Princeton University Press), Postmodern Spiritual Practices: The Reception of Plato and the Construction of the Subject in Lacan, Derrida, and Foucault (2007) (Ohio State University Press), and, finally Diotima at the Barricades: French Feminists Read Plato (2015) (Oxford University Press).

Miller's interest in philosophy and Plato in particular is made manifest in the very first chapter of the reviewed volume, "Roman Socrates: Irony in the Satires" (pp. 17-49), in which creatively builds upon a famous essay by William Anderson of a similar title ("The Roman Socrates: Horace and His Satires," in: J. P. Sullivan (ed.), Critical Essays on Roman Literature: Satire, London 1963, pp. 1-37). Setting the volume's tone with a rather weighty exposition on Horace's philosophy, Miller veers towards convolutedness; however, his saving grace is his clarity of phrase and scrupulous avoidance of philosophical jargon.

What guides and animates the entire compact volume is Miller's passion for Horace's poetry and his search for reasons for Horace's enduring popularity and unchanging relevance ("Introduction: Why Horace, Why Now?," pp. 1-15). Clearly, Miller has his opinions on why Horace remains relevant, but he avoids forcing them upon his audience; instead, he presents the evidence and encourages his readers to consider it carefully. Working in this almost-Socratic manner, Miller aims above all to capture the staggering complexity of Horace's works, the luster of his ambiguity and the power of his imagery. 
Resultantly, Horace appears as a poet of contrasts: an eulogist of personal freedoms yet also a supporter of Augustus's imperial politics; a masterful imitator of Greek iambic poets Archilochus and Hipponax; a sharp-witted, sarcastic satirist able to wolfishly bite back his opponent and yet simultaneously a peaceful philosopher enjoying his prosperous life; an involuntary moralist but also a trusted teacher of morals. Miller carefully unwraps and explores all these dualities of the poet-philosopher in the following three chapters: II - "Going Soft on Canidia: The Epodes, an Unappreciated Classic" (pp. 51-80), III - "Exegi monumentum: Horace's Two-Eared Odes" (pp. 81-127) and IV "Freedom, Friendship and the Ties that Bind: Socratic Irony in Epistles I" (pp. 129-177).

Miller supports his readings with copious quotes from Horace's works, in Latin and Miller's translations in English. Such excerpts are elucidated with his inspired interpretations, taking the form of short essays that familiarize the general reader with the inner workings of the philological method. Particularly praiseworthy is undoubtedly Miller's extensive analysis of the well-known Ode 1.9 (pp. 88-100), showcasing the poet's extraordinary artistry in matters of diction, allusion and irony.

Perhaps the weakest part of the volume is its perfunctory "Epilogue" (pp. 179-183), a cursory review of selected references to Horace's works in later periods. In my subjective opinion, its epitomic and compact nature does not quite fit the level of sophistication, depth and elegance exhibited by previous chapters. Possibly, the epilogue's limitations come not from Miller but result from general constraints of the series and the limited volume space.

One can hardly expect any groundbreaking insight from a publication devoted to such a popular author as Horace; nevertheless, Paul Allen Miller's synthesis manages both to thoroughly educate its audience on Horace's dazzling ambiguities and yet whet their appetites for more to come. Thanks to Miller's book, Horace continues to spin his webs of delight, and it can be said without a doubt, that the poet has not yet said his last word.

Bartosz Jan Kołoczek (Jagiellonian University in Kraków) 